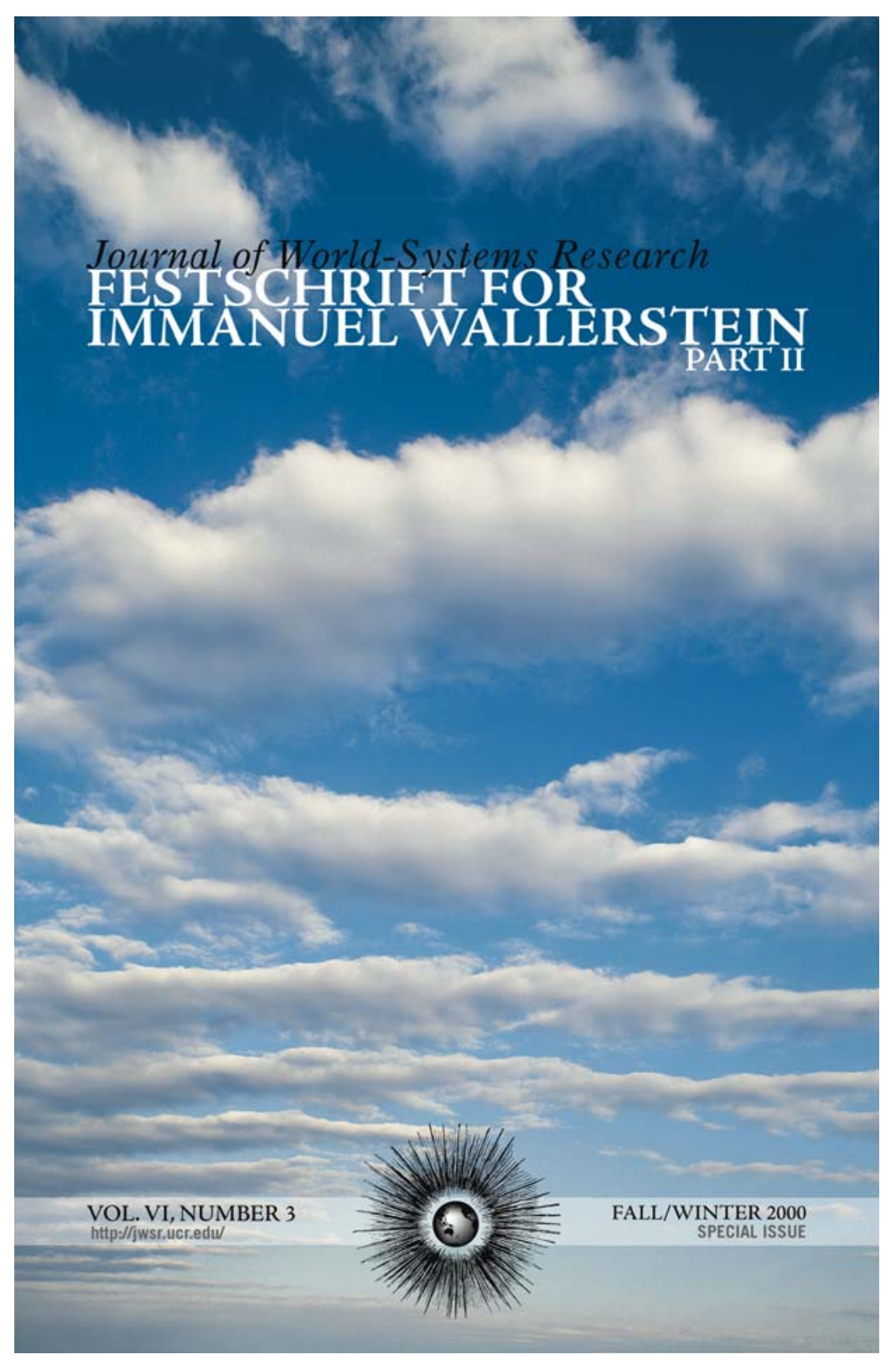

\title{
World-Systems Analysis, Globalization, AND INCORPORATED COMPARISON*
}

Philip McMichael

INTRODUCTION

】hen Immanuel Wallerstein (1974) subverted the mid-1970s social W science scene with his concept of the 'world-system,' development, the 'master' concept of social theory, suffered a fatal blow. Wallerstein's critique of development emphasized its misapplication as a national strategy in a hierarchical world where only some states can 'succeed.' Wallerstein's path-breaking epistemological challenge to the modernization paradigm reformulated the unit of analysis of development from the nation-state to the 'world-system.' To be sure, the past three decades have seen reformulations, coined to address the failures of the development enterprise: from basic needs, through participation in the world market, globalization, to local sustainability. But development, the organizing myth of our age, has never recovered.

The world-systemic critique of development succeeded in part because of its relevance to world conditions at the time. National developmentalism was unraveling as the shortcomings of the first development decade were becoming clear, and as a global money market formed. The currency of the world-system critique owed considerably to the terms in which it was

Philip McMichael

Department of Development Sociology

Cornell University

118 Warren Hall

Ithaca, NY 14853

http://www.cals.cornell.edu/dept/devsoc/

pdm1@cornell.edu

* I wish to thank Dale Tomich and Rajeev Patel for valuable suggestions on earlier drafts.

JOURNAL OF WORLD-SYSTEMS RESEARCH, VI, 3, FALL/WINTER 2000, 68-99

Special Issue: Festchrift for Immanuel Wallerstein - Part II

http://jwsr.ucr.edu

ISSN I076-I56x

(C) 2000 Philip McMichael 
made. By positing a broader analytical unit, world-system analysis was able to accommodate the phenomenon of the New Industrial Countries (NICs) at the same time as world inequality across the historic north/south division endured. And explaining world inequality was the overriding point of analytical departure.

Development was now posited as a systemic process, where coreperiphery relations were the real development dynamic and core states were outcomes, rather than units, of development. Nevertheless, within the definition of the 'world-system' (an antinomy of states and a single division of labor), states manipulated markets with varying degrees of success, comprising the state-system hierarchy. The hierarchy is expressed geographically, and understood phenomenally, in developmentalist terms (where core states monopolize the benefits of accumulation). Arguably, the geographical dimensions of the concept of the world-system produce a developmentalist reading of the unequal outcomes of the systemic process.

In this essay I want to address this dilemma, which Friedmann (1980) once characterized as a problem of conflating the object and the unit of analysis, where the concept of the world-system merges with its empirical, or geographical dimension. This dilemma has grown with the accelerated compression of time and space associated with the current era of 'financialization' (Arrighi 1994). Hoogvelt observes that (from Marx) the annihilation of space through time (via circulation of money and information) now re-orders economic activities into two kinds: 'real-time' economy "where distance and location are no longer relevant," and 'material' economy "where there is still some 'friction of space' that limits choice of location" (1997: 121). In this formulation, money itself is now a 'real time' resource, permitting an unprecedented degree of global mobility such that "the structure of core-periphery becomes a social division, rather than a geographic one" (Hoogvelt 1997: 121, 129).

I propose to address this dilemma by examining the 'internal' dynamics of capitalism, namely, the changing complex of monetary and wage relations across time, and how this is expressed politically. This approach avoids an empirical, or geographical ('external') point of departure, and reconstructs the world capitalist economy as organized by these fundamental relations. This difference is captured, for example, in alternative conceptual approaches to theorizing capitalism. Wallerstein (1979: 127) defined capitalist relations of production by 'the relations of production of the whole system,' including wage-labor as well as non-wage-labor, thereby asserting systemic primacy. Although this definition transcended the sterile definition of capitalism by wage-labor advanced by Brenner (1977), the ensuing debate about the status of wage-labor obscured the importance of distinguishing wage-labor as a theoretical concept and as empirical reality (cf, Tomich 1998). Theory and historical reality were conflated, and wage-labor itself was given no special theoretical significance.

While wage-labor is never the majority form of labor in the global economy, it is nonetheless the core of any historical theory of capitalism. Marx viewed wage-labor as the organizing principle of a world capitalist economy which included non-wage forms of labor, valorized through their relationship to wage-labor. In this essay, I explore this claim, not to resolve the debate, but because I believe it contains an indispensible methodological insight for developing historical theory. In relation to this discussion, it offers an alternative to the untheorized and historically unspecified concept of the relations of production of the whole system.

Wallerstein's claim that the world-system (in particular its single division of labor) operated through a variety of labor forms, suggested a hierarchy of labor skills which empirically correlated with a hierarchy of productive activities or products. This view reproduces the notion of an (evolving) historical continuum, whereby states could move up or down the hierarchy, and it has given life to the commodity chains line of inquiry (eg, Gereffi and Korzeniewicz 1994). Insofar as the hierarchy privileges industrial technology, it has tended to correlate with state commercial and military power. However, now, when industrial and informational technologies are organized trans-nationally by strategic corporate alliances, and/or the fruits of such technologies are no longer guaranteed to their home states and citizens, world-systemic hierarchies coincide less and less with states and/or their labor relations. In order to address this discrepancy, which is deepened by the growth of 'real time' economy, I invoke a form of historical theory that does not presume a structure, but views structure as formed through specific historical relations. The method of 'incorporated comparison' is a vehicle of historical theory (McMichael 1990). 


\section{INCORPORATED COMPARISON}

Incorporated comparison makes three particular claims. First, comparison is not a formal, 'external' procedure in which cases are juxtaposed as separate vehicles of common or contrasting patterns of variation. Rather comparison is 'internal' to historical inquiry, where process-instances are comparable because they are historically connected and mutually conditioning. Second, incorporated comparison does not proceed with an a priori conception of the composition and context of the units compared, rather they form in relation to one another and in relation to the whole formed through their inter-relationship. In other words, the whole is not a given, it is selfforming. This is what I understand we mean by historical 'specificity.' Third, comparison can be conducted across space and time, separately or together.

Cross-space comparison specifies a single conjuncture as combining particular spatially-located parts of a global configuration (such as an international food order, a debt regime, or the commodity complex of oil, or wheat, or micro-circuitry). On the other hand, cross-time comparison specifies an era as composed of temporally differentiated instances or versions of a world-historical process (such as state-building, or revolutions). Arrighi employs an additional form of incorporated comparison in The Long Twentieth Century, where he compares cycles of accumulation that represent interconnected eras, or episodes, in "a single historical process of capitalist expansion which they themselves constitute and modify" (1994: 23). The comparison is employed not to contrast these episodes, as disconnected cases, but to inform analysis of the current era through the logic of comparative inquiry incorporated into the problematic itself. Here, episodic sequences are understood as distinctive precisely because history itself is cumulative

In this essay, I employ the method of incorporated comparison to attempt to specify contemporary 'globalization.' I start from the premise that since capitalism has always been global, the current emphasis on globalization and 'free trade' needs to be explained as well as historically specified. Using an incorporated comparison approach, I juxtapose the present era of 'globalization' with that of the nineteenth century, when the British state sought to construct a 'self-regulating market' in much the same terms. I contend that globalization is a strategy of 'market rule' advanced by political and economic elites via institutional coercion. Such institutional coercion depends on a market equilibrating mechanism, combining wage-labor as the standard of value and a monetary form to express this standard. Present-day globalization repeats the British strategy for organizing world capitalism, but under quite different conditions, namely the absence of a world-money like sterling and a stable wage-labor regime.

The difference between conventional comparison and incorporated comparison is the point of departure and therefore the analytical outcome. Incorporated comparison views all objects of inquiry as historical and historically connected. Unlike conventional comparison, cases cannot be abstracted from their time/space location, via an experimental logic which juxtaposes cases 'externally', in order to generalize from observed patterns. Rather 'cases' or instances are understood as relational parts of a singular (historically forming) phenomenon. Comparison is incorporated into the very process of defining the object of analysis, whether parts or whole. Comparative analysis incorporates historical time into the inquiry itself, so that the object of inquiry is historically distinct, either because the instances themselves (e.g. individual states) inhabit particular and uneven time/space relations, or because the combined process (e.g. state-system formation) is constituted by these distinct but related instances of state-building. In other words, the instances and the combined process are not independent of one another, and cannot be adequately understood outside of the historical relations through which they form.

In this case, British market rule and the current era of 'globalization,' or 'free trade,' are juxtaposed as episodes of (unstable) capitalist hegemony, where the price form and market rhetoric are the organizing principles of political economy. The point is to use the juxtaposition to specify contemporary 'globalization.' The latter cannot be understood simply as a quantitative or qualitative change in the organization of world capitalism, rather it is a recurrence of an earlier episode, but via the resolution of its crisis. Comparison serves to relate the episodes as both a sequence and new specification. Since the goal is to specify 'globalization,' the method is one in which comparison constitutes the substance of the inquiry rather than its framework.

\section{MECHANISMS OF MARKET RULE}

The British state was engaged in unifying the world through the market, but the world was not a universe of nation-states, as it is today. It was a 
clustering of states, colonial territories and beyond. The British task was to construct a world market by institutionalizing market mechanisms in the practices of states and their colonial administrations. The gold standard was the key mechanism by which Britain unified the various political jurisdictions in the world market. All states and administrations were constrained to manage currencies in relation to the universal standard, gold price. As Polanyi (1957) points out, the standardisation of currency management was simultaneously a process of state-building: the currency was the nation. This national movement was indeed a form of globalization of market institutions and processes, but it was presented in national terms.

Today, the world market is already a unity, embedded in a system of national states. Arguably, this system of national states matured via a developmentalist project in which citizen-states subordinated markets to public goals. There was of course great variation in efficacy in this movement, especially as it extended to postcolonial states with less public capacity and immature home markets. Nevertheless, universally, capital was constrained by the priorities of rebuilding, stabilizing and constructing national economies. A compact with organized labor, and domestic social stability concerns such as full employment, rural subsidies and the social wage, were deeply imprinted in the state system of the mid-twentieth century. But the social and political constraints on capital became targets for a capitalist counter-movement in the last quarter of this century. By the 1970s there were rising demands for a reduction in these social priorities and constraints on capital, as the contradiction between wage-labor as a cost of production and as a source of demand grew in an internationalizing and inflationary conjuncture. Controls on the international circulation of capital were lifted, and states reduced their social responsibilities.

The attempt to (re)impose market rule required a different rhetorical and institutional strategy than the national developmental strategy associated with British hegemony. 'Globalization' emerged as a project asserting the global relations of capital, and a strategy for realizing these relations through removing political and social constraints. The disciplining of labor and the associated shrinking of the citizen-state are the central targets of the globalization project. The project of globalization is not simply a reflex by capitalist elites to rollback social claims on private profits. It is a historical response to the contradictions emerging within the Bretton Woods system of government controls on the circulation of money. While the Bretton Woods monetary regime privileged national economies and controls, private capital, aided by US dollar credits, developed transnational operations. Pressure on the dollar from transnational enterprise eventually undermined the Bretton Woods system of monetary controls, encouraging the decoupling of money capital from productive capital, and strengthening the foundations of market rule.

Market rule enlarges the space for circuits of money and commodities. The concept of 'globalization' implies a borderless world, where stateless money can pursue efficient, low-cost production, and/or speculation in active financial markets. In order to construct such a world, the proponents of globalization seek to institutionalize their rhetoric in structurally adjusted states, free trade agreements and global agencies geared to managing the world market.

Just as Polanyi argued, the attempt to impose market rule requires an institutional strategy. But Polanyi was addressing a very different context, where markets in land, labor and money had to be created through institutional means. In the present conjuncture, such markets have to be released from regulatory constraints. This does require an institutional strategy, but it is quite distinct from that of the nineteenth century. It expresses itself in the active decomposition of those social forms through which capitalism emerged and matured, namely, wage-labor and the nation-state. As I shall argue, these social forms are integral to one another, such that their decomposition is mutually conditioning. Further, understanding their current relations of decomposition requires understanding their formative historical relations.

The method of incorporated comparison allows us to analyze these two eras of market rule as composed of historically specific wage and monetary relations, with differential consequences for the nation-state across time. In short, the current era of 'globalization,' however similar as a project of market rule, signals the decomposition of social forms that tend to be taken for granted, but are quite historically contingent.

\section{BRITISH MARKET RULE}

In Polanyi's discussion of the attempt to install a 'self-regulating market' (SRM) in the nineteenth-century world, he implicitly suggests that it was a 
confidence trick. On the one hand the SRM was a utopia, or a fiction, and on the other hand, the SRM had definite institutional footprints. That is, British and other national legislation instituted the gold standard as the key institutional mechanism unifying the world market. But the gold standard itself was a fiction, in the sense that its automaticity was impossible in reality (gold could neither be produced on demand in an expanding market, nor physically be able to settle all balance of payments deficits). Therefore, it had to be institutionalized in national banking systems empowered to manipulate the supply of credit money in response to changing trade relations. The overriding imperative was to avoid the deflationary potential of a real gold standard.

In a world market where national exchanges needed stabilization, the management of exchange rates in relation to the gold price maintained the fiction of a true world money. The ideal remained insofar as trading countries were constrained to hold sterling balances as equivalents of gold in order to stabilize the value of their currencies. Through this institutionalization of the ideal of a gold standard, Britain retained its hegemony insofar as sterling represented gold as the world money, and the City of London was empowered to manipulate sterling balances to approximate the relatively frictionless movement of a world money among states requiring foreign exchange.

The premise for this arrangement, whereby Britain administered world market rule through the sterling/gold standard (world money), was the 'workshop of the world' strategy to impose a new 'colonial system' writ large through formal and informal empire. Concretely, the 1834 Poor Law Act and the Bank Act of 1844 together institutionalized the English labor market and central banking system, stabilizing accumulation, while the repeal of the Corn Laws in 1846 stimulated cheap grain imports from the 'New World' to reduce the cost of wage foods. Together, these measures instituted the markets in labor, money and land that underpinned Britain's prodigious commercial expansion on a global scale. In turn, Britain and the European states gained access to a broadening array of tropical products from the colonies (such as sugar, tea, coffee, oils, cotton, jute, rubber), and temperate products (grains and meat) from the settler states of North America and Australasia to fuel industrial capitalism (Friedmann and McMichael 1989).
While British measures to institute commodity markets subjected the ninteenth-century world to the dynamics of industrial capitalism, they also generated a protective cycle of market regulation across the world of constitutional states. In this movement lay the various national forms of regulation: land markets and agricultural trade generating agricultural tariffs (early food security politics); labor markets generating social democratic responses (in domestic labor legislation and early import-substitution industrial strategies); and a world money market generating currency management to stabilize national economic relations. Polanyi emphasized the "constitutive importance of the currency in establishing the nation as the decisive economic and political unit of the time" (1957: 203). In short, the protective response was formative of the nation-state. In these terms, the nation-state was a social form through which the world market was secured and capitalist relations were expressed politically.

Polanyi viewed the nineteenth-century world, through the prism of the SRM, as an ideal construct institutionalized in commodity markets in land, labor and money. His point of departure was the fetishism of commodity relations. But Polanyi, unlike Marx, never explained the source of this fetish. For Polanyi, by accepting the economistic fallacy, humans condemned themselves to the drastic unintended social consequences of market forces and counterforces. For Marx, commodity fetishism obscured the social relations underlying the market. That is, value relations between people and classes presented as value relations between things, in particular, commodities and their prices. Viewing market relations solely in terms of these phenomenal forms condemns the observer to an ahistorical understanding of the market. In this sense, one can say that Polanyi's instituted market' is almost as ideal-typical as the economic liberal's naturalized conception of the market (the SRM) against which he launched his critique.

Marx's theory of capital posited a universe of commodity production and circulation, in which the regular exchange of commodities as use-values generates a universal commodity in which all commodities express their value. This is the money commodity, the mother of all commodities. By expressing and mediating the exchange values of a variety of concrete commodities, money assumes the value form and comes to be regarded as the embodiment of value. Theoretically, a world money is a money commodity through which all national currencies express their exchange value. In order 
to sustain credibility, world money took the form of gold/sterling which, in the nineteenth century, became the standard in which currency values were expressed in order to facilitate their mutual exchange.

Again, theoretically, a universe of commodity production and circulation requires a generative principle by which value reproduces and self-expands. Marx's conception of wage labor met this requirement insofar as it produced surplus-value through the property relation. The right to dispose of, and then to consume, labor-power fulfilled the double condition of the wage contract as a phenomenal relation obscuring the workplace relation of exploitation, wherein lies the self-expanding power of capital. The wage relation is both an act of exchange and an act of exploitation. Here, Marx's concept of wage-labor as the source of valorization presumes a world of commodities on the one hand, and a historical process of expropriation on the other. Regularized market exchange and capital accumulation depend not simply on the perception (or fiction) of commodification, but also on a definite historical process whereby relations of private property stand behind a labor market. Under these conditions, capital is nothing without the wage relation through which to enlarge its command of value-producing labor. The value produced is theoretically determined by the relational concept of socially-necessary labor time whereby commodities express their social worth. Thus the wage relation is the conceptual key to valorization.

Historically, Britain's market rule combined wage-labor with world monetary discipline in a single regime. Gold served as the universal equivalent, in value terms, of all national currencies. Through this mechanism this monetary regime incorporated other forms of labor into the wage relation. To the extent that states internalized the gold standard mechanism and organized their monetary policy around stable currency exchange, so they also imposed the requirements of capitalist valorization on their labor forces. For example, when the Turkish state levied taxes on its peasantry to deliver grain that in turn the state sold in European markets to earn foreign exchange (Luxemburg 1963: chapter 30) it linked the valorization process in Europe (proletarian consumption of wage foods) to the reorganization of peasant labor in Turkey, as mediated by world money. In other words, wage-labor was combined with peasant labor in a politically-mediated process of valorization: the instituted market.

Through this mechanism, a universal standard of money, expressing commodity equivalences, established the rule of the law of value in subjecting other forms of labor, such as slave labor (cf, McMichael 1991) and family farm labor (cf, Friedmann 1978) to the competitive dynamics of the industrial wage-labor system. Here, plantation production assumed an industrial rhythm (e.g., gang slavery) as factors advanced credit on delivery of cotton, and family farming depended on commercial inputs and world grain prices. While this regime combined diverse forms of labor, it was empirically centered in wage-labor, as the source of self-expanding capital. Through the circuit of world money, managed by national banking systems, non-wage forms of labor embodied the valorizing dynamics of wage-labor, and yet retained their different forms. In this way, wage-labor imposed its value requirements on non-wage forms of labor via the market rule of the gold standard. Under this regime, other forms of labor and national currencies expressed their value, respectively, through the wage form and gold. Historically, this global circuit of value of course depended on military force, the City of London's pivotal role in organizing sterling balances, and England's aggressive commercial apparatus (see Polanyi 1957, Ingham 1994).

Certainly, the world was complex and the world market was not exactly self-regulating (e.g., Britain used its positive balance of payments with India to sustain the world monetary role of sterling). But, proceeding from the concept of wage-labor to a historical account of the regime of wage-labor reveals the mechanism whereby capitalist valorization could be internalized by states within the gold/sterling monetary regime. In addition, the elaboration of such a regime, under the banner of 'workshop of the world,' indicates the global process of lowering the reproduction cost of wage-labor. By dismantling its Corn Laws, and determining the price of industrial labor by the cost of globally sourced wage-foods through the sterling-gold standard, British capitalism imposed a competitive valorizing logic on agricultural producers across this world.

\section{THE BRETTON WOODS REGIME}

The collapse of the British-centered world economy in the early-twentieth century resulted from a series of counter-movements against market rule, culminating in national and imperial conflict among European states. The gold standard disappeared, and the world experienced an unstable period of wars and depression before the crisis following the collapse of market rule 
was resolved. In the post-WWII world, monetary and wage relations were instituted nationally via the Bretton Woods regime of fixed exchange rates. This was a logical extension of the movement to embed the world market in national economic development priorities following the Great Depression (and/or 'the great transformation'). Developmentalism was anchored in a class compromise which subsidized First World labor through the social wage and in imperial relations geared to replicating the wage relation in the Third World. Capitalism was to be stabilized in national forms of accumulation.

The Bretton Woods monetary system supported the Keynesian principle of national full employment policy, and included capital controls, preempting a world money regime like the sterling-gold standard. Dollar/gold convertibility was mediated by the IMF, from which member states borrowed short term to stabilize their accounts in accordance with their initial gold deposits. In addition, fixing the value of national currencies in relation to the dollar subordinated monetary relations to U.S. foreign and domestic policy, constraining central banks to support the value of the dollar (Marazzi 1995).

Formally, there was no institutional mechanism for the American dollar to replicate the British pound sterling's role as a true world money anchored in productive value relations. The sterling-gold standard imposed monetary discipline directly upon firms via balance of payments adjustments, linking production and credit costs to world prices (of goods and currencies). Conversely, under the Bretton Woods monetary regime, macroeconomic policy mediated adjustment, protecting domestic economic agents through deficit financing to maintain national accumulation and the rising social wage. With 70 percent of world gold reserves, and a monetary regime geared to protecting the value of the dollar, American Cold War dollar credits sustained this process for a time-stimulating accumulation at home and abroad. But this could not be sustained for long, because fixed exchange rates compelled central banks to inflate their money supply to support the value of the dollar, and, with a growing Eurodollar market, international claims against the dollar (and its gold backing) ballooned. Dollar inflation revealed the political, rather than value, relations underlying the monetary regime. It also spawned an informal world money which eventually undermined Bretton Wood regulatory mechanisms (IMF adjustment and capital controls). International pressure from the Eurodollar markets forced the U.S. government in the early 1970s to decouple the dollar from gold parity, leaving an unstable system of floating currency exchanges (see Leyshon and Thrift 1997).

\section{MARKET RULE POLITICIZEDः THE GLOBALIZATION PROJECT}

The current, post-Bretton Woods era, rests on a system of floating currencies, with no single world money (including gold) to discipline currencies. The growth of an unregulated global money market (increasing arbitrage opportunities and raising the opportunity cost of fixed capital) and the uncertainty associated with the decline of US hegemony encouraged the process of 'financialisation:' a contagious preference for liquid rather than fixed capital on the part of private and institutional investors (Arrighi 1994). The new global money market accompanied bank deregulation, the process of securitization (tradable debt) and the proliferation of a variety of financial instruments creating new money out of expected future income (Hoogvelt 1997: 82). National currencies, especially the dollar, serve as variable means of international payment, and as such, they are the object of intense speculation in the global money markets. Under these conditions, there is no standard of value to discipline markets. The value of money is no longer determined by its ability to create surplus-value through the wage relation, but by its ability to command credit, since the stability of currencies depends on financiers' ongoing evaluation of national economic policies and on future income of borrowers. Such evaluation is political in two senses: in the assessment of potential for stable financial growth, and in the assessment of a state's commitment to global circuits of money and commodities, relative to other states.

To the extent that the wage form no longer governs valorization, other forms of labor are valorized directly through political or non-market mechanisms as investors seek to evade or weaken organized labor. Labor forces across the world are cheapened, with the recursive effect of devaluing the wage contract through familiar mechanisms such as the 'race to the bottom' (see Brecher and Costello 1994). De-institutionalization of the wage form expresses the connection between the project of globalization and the specific crisis of late-twentieth century capitalism. The crisis is that "not only can the international currency-the dollar-no longer be converted into 
gold, but money as capital itself can no longer be converted into effective command over labor" (Marazzi 1995:74).

In my view, the counter-mobilization of capital against the social and political constraints of Fordist/Keynesian developmentalism is reflected in a combined process of decomposition of the nation-state and wage-labor. The growing casualization of world labor reduces capital's foundation in wage-labor as investors who are not bypassing production to speculate in global money markets target quite flexible labor options. The decomposition of wage-labor erodes the foundations of the nation-state in the institution of wage-labor from the 'inside,' as structural adjustment and liberalization decomposes the nation-state, as a social institution, from the 'outside.' This captures the essence of the globalization project, leading one commentator to observe that contemporary capitalists are concerned less with the reproduction of wage-labor, and more with the reproduction of money (see Hoogvelt 1997).

The political core of globalization lies in the crisis of developmentalism, where the public rhetoric is jobs and competitiveness, but the private reality is financial dealing and the casualization of labor. Export processing zones proliferate, using coercive labor relations where the value of the labor reimbursement bears little relation to the labor power expended. The more generalized this phenomenon, the greater the pressure on the institution of wage-labor, in addition to the destabilizing consequences of this speculative era of financialization, as we have seen in the Mexican, East and Southeast Asian, and Russian financial crises.

The political foundations of this financial regime solidified in the management of the 1980s debt crisis. Debt management empowered the multilateral financial institutions, especially the IMF, which joined with the World Bank in establishing a distinctive form of politicized market rule. In place of the automatic, or nationally mediated, adjustment of currency values associated with a world money system, we now have an overtly politicized operation led by international monetary fundamentalism. It is politicized in two senses: first, structural adjustment loans and programs are directed at debtor states (i.e., their citizens) and not the banks holding their debt-expressing the new power of financial capital; and second, adjustments are not simply economic, they are profoundly political in reorganizing state structures and policies according to neo-liberal dictates of private efficiency-expressing a form of financial colonialism (McMichael 1995).

The first condition for loan rescheduling laid down by the IMF is currency devaluation. Currency devaluation, imposed via IMF supervision via Article VIII of the IMF Articles of Agreement (on about 90 member states so far), represents both an attack on the national currency and, following Polanyi, on national sovereignty. Devaluation compresses real earnings, as domestic prices of food staples, essential drugs, fuel and public services inflate. Governments are then constrained to pursue anti-inflationary programs, shrinking the state through reduction of public expenditure including social programs, and de-indexing wages to promote "liberalization of the labor market." These conditions not only reduce national policy choices, but standardize them as well (to the extent that they do standardize in practice). They also demand political independence of Central Banks allowing the IMF to handle money creation, which means resuming dependence on foreign loans. In global terms, IMF conditions reduce the value of labor in hard currency, and adjust domestic prices upward, reinforcing the globalization of poverty' (Chossudovsky 1997:56-9).

The cumulative effect of individual country adjustment is a general global restructuring, whereby labor costs are ratcheted downwards through de-indexation and the elimination of social wage supports. With the realignment of domestic prices to reflect world prices, and the exposure of unprotected domestic labor forces to the depressive forces of a world labor market, market rule is instituted through the collaboration of multilateral power and domestic political and economic elites who profit from state privatization schemes and loan rescheduling. In effect, this unrestrained money power-unrestrained because money is now more a political relation than a value relation-privileges multilateral financial institutions (and TNCs) and reconstitutes state power around the implementation of monetarist orthodoxy (see Marazzi 1977:107).

\section{THE DECOMPOSITION OF WAGE-LABOR}

In a global economy where value is no longer rooted in the effective command of wage-labor, much generation of wealth is artificially created by credit, accelerating the concentration and centralization of capital and its technological base (devaluing wage-labor), and intensifying the consumption of productive and increasingly non-productive (e.g. symbolic) commodities. 
The implementation of neo-liberal, supply-side, economics has generated a crisis of overproduction, as consumption has not matched the expanded global production base; for example, prior to the global financial crisis, in 1997 the global auto industry had the capacity for 80 million vehicles a year, for a marketplace with fewer than 60 million buyers. Such overcapacity puts pressure on firms to lay off workers and relocate to reduce their labor costs, further exacerbating the problem (Greider 1997).

The integration of the world labor force is a condition of global strategies of accumulation. Under the terms of the micro-electronics revolution, the production and appropriation of information has become central to accumulation. Not only do information technologies facilitate flexible global organization, but also this form of accumulation values, and depends increasingly on, market 'place.' Firms increasingly depend on the quality of their relational links (sometimes in alliances with competitors), their ability to extract market information, and their coordination of clusters of subcontracting relations. That is, the modern, vertical integration and pyramidal structure of firms is yielding to a more horizontal integration, where decentralized databases interlock and exchange information, and power diffuses into a series of connected command nodes, in which "to be powerful is to be in contact, in communication, and in which power is defined by influence and no longer by mastery" (Guéhenno 1995:62)—although firms retain production facilities that are essential for maintaining strategic control (Sengenberger and Wilkinson 1995:113).

The new industrial space has been characterized as geographically discontinuous, because of "the technological and organizational ability to separate the production process in different locations while reintegrating its unity through telecommunications linkages, and microelectronics-based precision and flexibility in the fabrication of components" (Castells 1996: 386). Unlike the world-system/commodity chain approach to global industrial organization, which focuses on a geo-politically derived hierarchical division of world labor in the conception and fabrication of a products, the notion of a 'space of flows' situates hierarchies of innovation and fabrication in global networks. Here the "direction and architecture of these networks are submitted to the endless changing movements of cooperation and competition between firms and between locales, sometimes historically cumulative, sometimes reversing the established pattern through deliberate institutional entrepreneurialism" (Castells 1996:393).
A complementary perspective views corporations adopting a "loosely confederated network structure" in order to survive in and negotiate an environment where markets and technologies are in constant flux. Since the global market now integrates a global core of middle class consumers, corporations combine global coordination with regional marketing strategies (including purchasing local firms to establish a regional foothold). Informational technologies facilitate this, but are both expensive and rapidly obsolescent, "placing an ever greater premium on access to financial resources, multiplant production and extensive marketing networks" (Hoogvelt 1997: 110). The consequence is that companies (high-tech industries such as automobile, aerospace, computers, and telecommunications) enter increasingly into strategic alliances and joint ventures, giving rise to the 'networked' or 'virtual' firm. The virtual firm is governed by financial mergers and speculation, and a disregard for labor force reproduction in any particular place (Hoogvelt 1997:111, 113). In this configuration, social rather than geographical hierarchies (as understood in the classic international division of labor between north and south) organize a global production landscape that is fluid, unstable, and characterized by 'jobless growth,' overproduction tendencies, and recurring outbreaks of financial crisis.

From the enterprise point of view, the greater differential in labor standards encourages 'rent seeking,' whereby companies improve their profitability by "specializing in extracting concessions from workers, locally based firms and from communities" (Sengenberger and Wilkinson 1995:123). This practice, which contributes to the 'race to the bottom' dynamic, also expresses the financially-driven practices of what is appropriately termed 'predatory capital.' The U.S. stands as the model of this kind of rent-seeking versus new wealth creation: "federal law limits the ability of individual states to regulate corporations where labor standards vary between states, and where legislative changes and judicial judgements have made it increasingly easy to dislodge trade unions and to dismantle collective bargaining" (Sengenberger and Wilkinson 1995:123). Also, the U.S. government, unlike European states, allows companies to hire part-time employees without traditional full benefits, thus creating millions of new, second-class, jobs.

In a globalizing economy, firms in other states with more intact social rights are unlikely to stay put when they can gain access to global money markets and locate in regions where labor standards are more conducive to profitability. These conditions encourage the 'export' of the U.S. labor 
model. The logic of the globalization project (including regional trade bloc formation) is precisely to universalize conditions for this kind of predatory capitalism by institutionalizing a global property regime-reducing government intervention in financial markets, and subordinating national laws to the rights of flow (in and out) of investment capital. Such a regime is currently under discussion in the stop-and-go MAI talks, initiated by EU states and businesses, with the support of the US and Japanese governments.

The global property regime rests on the casualization of the wage relation-bringing wage-labor into competitive juxtaposition with increasingly casual, sweatshop, prison, slave and child labor. In China, for example, where almost half the world's shoes are made, along with an array of garments, household gadgets and electrical appliances previously assembled in Hong Kong, Taiwan and South Korea, factory management is militaristic and punitive (Chan 1996:21). While there is great variation across regions and plants, the premium on flexibility encourages informal labor markets and conditions. In fact, across the world unskilled labor straddles the divide between the formal and the informal economy, with a more pronounced foundation for capitalist production in unregulated and highly-exploitative environments.

In a historical conjuncture where the wage form governs value production and exchange less and less, non-wage forms of labor become at once increasingly significant and increasingly tenuous. Included in non-wage forms is the semi-wage, or temporary hired worker. Collins has documented recent trends towards the feminization of Latin American agricultural workforces. Agribusiness firms hire women to combine high-quality labor with the lower costs associated with the flexible employment patterns of women, which is related to their primary responsibility to provision their household - in other words capitalist social relations are not simply market relations, but implicate household relations also as part of their conditions of reproduction. Collins concludes: "Agribusinesses use gender ideologies to erode stable employment and worker rights where women are concerned. Of equal significance, employing women provides the employer with a way of invoking institutions beyond the workplace to extend and reinforce labor discipline" (1995:217).

My point is that in a world market where valorization has to be managed, social and cultural conditions beyond the formal labor market enter directly into the construction of labor forces vulnerable to human and labor rights abuses. In Chile, the show case of structural adjustment, the Labor Code formally resembles the informal practices in the U.S. labor market, that appear to be the latest American export. That is, it allows "employers to fire workers at will, individually or en masse, for 'business necessities,' eliminating, according to the architects of the code, the 'monopoly' many workers had on their jobs...the right to organize was extended only to workers employed for at least six consecutive months" (Watkins 1996:160). This includes the much-heralded Chilean fruit industry where women work a few months a year, on a piece rate basis - a standard feature of a labor market where the wage relation is not regulated by the law of value.

The revival of sharecropping in California can be interpreted as a class strategy on the part of growers to undercut the power of organized farm labor. Not only are sharecroppers "essentially employees with a share feature to their wage contracts" (Wells 1996:302), but also they use labor contractors to hire devalued labor:" research shows that the use of contractors lowers wages and benefit levels, impedes labor organizing, increases worker dependency, and reduces the likelihood that employees will pursue their rights under the law" (Wells 1996:299). In world-historical context, the decline of the Californian wage contract and the rise of sharecropping articulates with the Mexican subsistence, or informal, sector, which subsidizes severely underpaid and underemployed laborers on sharecropper plots (Wells 1996:285).

Here the decomposition of wage-labor expresses contradictory, politically-mediated relations between states, firms and labor. The diversity of labor forms suggests something more than simply a new era of flexible capitalism, pursuing lower labor costs, resources and perhaps quality control. Arguably, these developments are quite specific to this world-historical conjuncture. Wage-labor is less and less an anchor of capital accumulation, which depends more and more on undercutting wage-labor with bastard forms of labor from around the world. The relations of production of the whole system are certainly relevant, but, in my view these relations are only understandable as governed by the counter-movement of capital against wage-labor and its power, as historically institutionalized in state social policies. In other words, the systemic relations of production need to be situated historically, within a comparatively informed understanding of the conditions that formed and now deform the wage-labor relation. 


\section{CONCLUSION}

Contemporary 'globalization' is a multi-dimensional class project. Institutionally, it matured during the 1980s debt regime, and it repeats the attempt to install a self-regulating market, this time in place of nationally instituted markets. Market freedom today means a frontal assault on the institutions of the nation-state (or citizen-state). However, states are not being eliminated, rather they are being restructured from nation-states into what I shall call 'global' states, that is, institutions geared to securing global credit, and circuits of money and commodities, and usually legitimized by 'consumer citizens.' This is clear enough from the European initiative to establish a single currency via the centralization of monetary policy.

I have argued that the decomposition of the nation-state is synonymous with the decomposition of wage-labor as a social institution. Through the process of instituting the self-regulating market in the nineteenth century, the formation of the nation-state was conditioned by the existence of a global political-economy pivoting on the wage-labor relation. The ideology of development, the process of decolonization, and the construction of social-democractic, and developmentalist, state forms all depended on the unification of the world market via the maturing wage relation. The rise of social labor was central to the universalization of the nation-state, which combined Fordist/Keynesian state forms with the stabilization of the global economy via developmentalist states in the non-European regions of the world.

The 'globalization project' reversed this historical process by de-institutionalizing monetary relations and wage relations. Relaxing national labor standards and financial controls is clearly destabilizing. The "Washington consensus' is no longer a consensus-especially since the Asian financial debacle, which the World Bank blamed on the IMF and U.S. policy. Since money is no longer governed by commodity values, but rather by speculative circuits of financial capital, the globalization project also means avoiding financial collapse. National debt is underwritten and rescheduled on a decidedly ad hoc basis: as exemplified in the emergency bail-out of beleaguered Asian-Pacific national banking systems, by IMF packages supplemented with northern financial assistance. The IMF's role is to extract financial adjustment in the assisted states to sustain global capital flows, bailing out the banks at the expense of citizens.
The lesson here perhaps is that capital is unable to regulate itself without a world money commodity as the vehicle of the law of value. In its place, we have powerful debt security or bond-rating agencies, like Standard and Poor, and Moody's (combined listings of 3 trillion US dollars), and financial speculators, who privately regulate the disposition of investment funds and the value of national currencies, respectively, according to financial orthodoxy (Sassen 1996:15-16). And, in the event of poor credit ratings, and short-term money flight, the IMF steps in as de facto lender of last resort. In other words, the need to preserve money increasingly governs institutional politics in global and national arenas, at the expense of the substantive social policies identified with the era of wage-labor and the nation-state.

In this essay I have attempted to problematize globalization as a historical project, by comparing two periods of market rule. In addition to the sequential, historical relationship between the nineteenth-century'self-regulating market' episode and the late-twentieth century era of globalization, there is a conceptual relationship between these episodes. This relationship is imminent in the history of wage-labor, and can be understood via two methodological devices. First, there is the method of political economy, which posits wage-labor as the conceptual key to the history of capital and its many social determinations. Second, the method of incorporated comparison brings these two episodes into relation to one another via analysis of the wage relation, understood as a global political construct with quite distinct social and institutional determinations across the two historical times. In this way, history is theorized via concepts that are relationally formed and therefore comparable in and across historical time.

\section{REFERENCES}

Arrighi, G. (1994). The Long Twentieth Century: Money, Power and the Origins of Our Times. Verso, London.

Brecher, J., and Costello, T. (1994). Global Village, or Global Pillage? Economic Reconstruction from the Bottom Up. South End Press, Boston.

Castells, M. (1997). The Power of Identity. Blackwell, Oxford.

Chan, A. (1996)."Boot camp at the shoe factory," The Washington Post/Guardian Weekly November 17: 20-21.

Chossudovsky, M. (1997). The Globalization of Poverty. Impacts of the IMF and World Bank Reforms. Third World Network, Penang.

Collins, J. (1995). "Gender and cheap labor in agriculture," in Food and Agrarian Orders in the World-Economy, (ed.) McMichael, P. Greenwood Press, Westport: 217-232. 
Friedmann, H. (1978)."World market, state and family farm: social bases of household production in an era of wage-labor," Comparative Studies in Society and History 20, 4: 545-86.

Friedmann, H. (1980). "Review of The Capitalist World-Economy, by Immanuel Wallerstein," Contemporary Sociology 9: 246-49.

Friedmann, H. and McMichael. P. (1989). "Agriculture and the state system: the rise and decline of national agriculture, 1870 to the present," Sociologia Ruralis XXIX, 2: 93-117.

Gereff, G. and Korzeniewicz, R. (1994). Commodity Chains and Global Capitalism Westport: Greenwood Press.

Greider, William. (1997). One World, Ready or Not: the manic logic of global capitalism. Simon and Schuster, New York.

Guéhenno, J-M. (1995). The End of the Nation-State.. University of Minnesota Press, Minneapolis.

Hoogvelt, A. (1996). Globalization and the Postcolonial World. The New Political Economy of Development. Macmillan, London.

Ingham, G. (1994)."States and Markets in the Production of World Money: Sterling and the Dollar," in Money Power and Space, (eds.) Corbridge, S., Martin, R., and Thrift, N. Blackwell, London: 29-48.

Luxemburg, R. (1963). The Accumulation of Capital. Routledge, London.

Marazzi, C. (1977)."Money in the world crisis: the new basis of capitalist power," Zerowork 2: 91-112.

Marazzi, C. (1995)."Money in the world crisis: the new basis of capitalist power," in Global Capital, the National State and the Politics of Money, (eds.) Bonefeld, W. and Holloway, J. St. Martin's Press.

McMichael, P. (1990). "Incorporating comparison within a world-historical perspective: an alternative comparative method," American Sociological Review 55, 3: 385-397.

McMichael, P. (1991). "Slavery in capitalism: the rise and demise of the U.S. ante-bellum cotton culture," Theory and Society 20: 321-349.

McMichael, P. (1995).“The 'new colonialism: global regulation and the restructuring of the inter-state system," in A New World Order? Global Transformations in the Late Twentieth Century, (eds.) Smith, D. and Borocz, J. Greenwood Press, Westport: 37-56.

Panitch, L. (1996). "Rethinking the role of the state," in Globalization: Critical Reflections, (ed.) Mittelman J.H., Lynne Reinner, Boulder.

Polanyi, K. (1957). The Great Transformation: The Political and Economic Origins of Our Times, Beacon, Boston.

Sassen, S. (1996). Losing Control? Sovereignty in an Age of Globalization. Columbia University Press, New York

Sengenberger, W., and Wilkinson F. (1995). "Globalization and labor standards," in Managing the Global Economy, (eds.) Michie, J. and Grieve, J. Smith. Oxford University Press: 111-134.

Tomich, D. (1998)."World of capital/worlds of labor: a global perspective," in Reworking Class (ed.) Hall, J.R. Cornell University Press, Ithaca: 287-312.
World-Systems Analysis, Globalization, and Incorporated Comparison.

Wallerstein, I. (1974)."The rise and future demise of the world capitalist system: concepts for comparative analysis," Comparative Studies in Society and History 16, 4: $387-415$.

Wallerstein, I. (1979). The Capitalist World-Economy. Cambridge University Press, New York.

Watkins, K. (1996)."Free trade and farm fallacies. From the Uruguay Round to the World Food Summit," The Ecologist 26, 6: 244-255.

Wells, M. (1996). Strawberry Fields. Politics, Class, and Work in California Agriculture. Cornell University Press, Ithaca. 